\title{
Rus Raporlarında Türkistan İsyanı (1916-1917)
}

\section{Turkestan Revolution in Russian Reports (1916-1917)}

\author{
Ömer Karataş ${ }^{1}$ []
}

${ }^{1}$ Sorumlu yazar/Corresponding author: Ömer Karataş (Dr. Öğr. Üyesi), Bandırma Onyedi Eylül Üniversitesi, İnsan ve Toplum Bilimleri Fakültesi, Tarih Bölümü, Balıkesir, Türkiye.

E-posta: omerkaratas410@gmail.com ORCID: 0000-0001-7177-8547

Başvuru/Submitted: 09.12 .2020 Kabul/Accepted: 15.03.2021

Atıf/Citation: Karatas, Omer. "Rus Raporlarında Türkistan İsyanı (1916-1917)." Avrasya incelemeleri Dergisi - Journal of Eurasian Inquiries 10, 1 (2021): 63-82.

https://doi.org/10.26650/jes.2021.003

\section{öz}

Çarlık Rusya'sı, Batı Türkistan'ı 19. asrın sonlarına doğru işgal etti. Ardından bölgeyi menfaatleri doğrultusunda sömürmek için idari, sosyal ve ekonomik düzenlemeler yaptı. Yapılan düzenlemeler neticesinde yaklaşık elli yıl bölgenin yer altı ve yer üstü kaynakları Ruslar tarafından sömürüldü. Daha sonraki siyasi gelişmeler neticesinde, özellikle I. Dünya Savaşı, sırasında çarlık yeni insan kaynağına ihtiyaç duydu. Çarlık, bu ihtiyacı karşılamak için daha önce askerlikten muaf olan gayr-ı Rusları orduya almak amacıyla 25 Haziran 1916'da bu tarihten önce bir ferman çıkardı. Söz konusu fermanla Türkistan'ın gayr-ı Rus bölge ahalisini orduda istihkâm işlerinde çalıştırmak isteyen Çarlık Rusya'sı, sömürünün insan kaynağına yönelmesine olanak tanıdı. Bu son gelişme önce Semerkant'ta başlayan daha sonra tüm bölgeye yayılan isyana sebep oldu. Türkistan'da çarlık rejimine karşı başlayan isyan ateşi Çar II. Nikolay tarafından 25 Haziran 1916'da çıkarılan ferman (yabancıların askeri arka işlere alımı) dışında çeşitli nedenleri de vardı. Bunlar Rus arşiv belgelerinde; siyasi, ekonomik, dini, sosyal yaşama müdahale, askerlik, vergi, yönetim, eğitim, adalet düzeni, Rus ve gayr-ı Ruslar arasındaki arazi çatışması, bölgedeki Rus ahalinin silahlandırıması; bunların kendilerini üstün görmesi gibi nedenler olarak sıralanabilir.

Çalışmamızda Türkistan Millî Ayaklanmasını Rus raporlarına dayalı olarak ele alınacaktır. Böylece Rusların isyanı nasıl algıladıkları ve değerlendirdiklerini onların yazdıklarından ortaya konacaktır.

Anahtar kelimeler: Türkistan, İsyan, Çarlık, Millî Ayaklanma

\section{ABSTRACT}

The Russian Czar invaded West Turkestan toward the end of the 19th century. Subsequently, he made administrative, social, and economic arrangements to exploit the region for his interests. As a result of the regulations, the underground and aboveground resources of the region were exploited by the Russians for approximately 50 years. As a result of subsequent political developments, especially during World War I, czarism needed new human resources. To fulfill this need, the Czar issued an edict on June 25, 1916, to recruit individuals exempted from military service before this date. By implementing this decree, the Czar of Russia, who wanted to employ the non-Russian inhabitants of Turkestan in fortification works in the army, enabled the exploitation to be directed toward human resources. This latest development led to the rebellion that first started in Samarkand and then spread throughout the region. The rebellion fire that 
started against the czarist regime in Turkestan was Czar II. Apart from the edict (recruitment of foreigners to military rear jobs) issued by Nikolai on June 25, 1916, there were also various reasons. These are in Russian archive documents and are as follows: political, economic, religious, social life intervention, military service, tax, administration, education, justice order, land conflict between Russians and non-Russians, and arming the Russian people in the region. The reasons such as the Russians considering themselves superior are listed as reasons. There were other reasons as well. In our study, on the basis of Russian reports, we consider the Turkestan National Revolt and reveal how the Russians perceived and evaluated the rebellion from their writings.

Keywords: Turkestan, Rebellion, Czarism, Report, National Revolt

\section{EXTENDED ABSTRACT}

In accordance with the expansionist colonist policy of Russian Czarism, the interest in Central Asia began during the period of Peter the Great. Peter the Great had an expedition to Turkestan, proving his interest. The expeditions led to gains such as improving the understanding of the region, building a fortified line, establishing outposts and fulcrum points.

Perceiving Peter the Great's interest in Turkestan as a political testament, he invaded the region in favor of czarism nearly 150 years later to please his successors who ascended the Russian throne. Czarist Russia invaded and annexed the Turkestan region until the last quarter of the 19th century, with the policy of taking, isolating, and dividing the Kazakh Juzes and then the Turkestan Khanates.

As a result of czarist expansionist and colonist politics, Peter the Great made legal arrangements between 1867 and 1917 to strengthen his political, military, and economic power in the region. In the formation of the Governorship of Turkestan, the region was divided into five administrative units: Semirechensk (Yedisu) Province, Sir Derya Province, Semerkand Province, Fergana Province, and Mavera-i Bahr-i Hazar (Beyond the Caspian Sea) Province.

The West Turkestan region is the region where the Russians operated the most. For this reason, detailed studies of this region were conducted before and after the occupation. The Russians were knowledgeable of the underground and aboveground resources of the region, mountains, mines, plains, rivers, arable lands, and population. On the basis of this information, the Russians systematically exploited the resources of the Turkestan region. This policy of exploitation continued for nearly 50 years.

Turkestan was captured by Czarist Russia, leading to its policy in the region collapsing in 1916. This collapse is one of the signs that the collapse of czarism is imminent. Notably, the Russian Czarist Era ended in 1917. However, this is not our point. The main point is the activities of Russia, which invaded Turkestan after the second half of the 19th century. To hold the dominance of the Turkestan Region, the Russians conducted ongoing activities to intervene in the habitats, management styles, economies, lands, and religious lives of nonRussian people. The response to the interventions of Czarist Russia manifested nearly 50 years after the invasion. The grudge and the sense of independence accumulated by the non-Russian 
people in Turkestan during this 50-year period against the oppressive authority manifested with the riots in July 1916. In August and September of the same year, the riots turned into a rebellion and reached their peak. The new decisions taken by the czarist government on the region are one example of the reasons that prepared the environment for these feelings to explode and the silence in the region to break down. As a result, the effects of the activities of the Russians, which started after 1867, against the ancient inhabitants of Turkestan, caused the events called the riot or the Urkün massacre in Turkestan. Our work is based on three reports on the Turkestan region prepared for czarism and the post-czarist provisional government:

1. The Turkestan General Governor and Turkestan Regional Military Commander sent to the Ministry of War for the presentation of the Czar by the Governor-General of Turkestan, the start of the rebellion, the financial losses in the places where the riot spread, the military measures implemented during the riot, the losses in the revolt, the treatment applied to the participants in the Turkestan revolt, and a detailed report. 22 февраля 1917 г.Копия.РГВИА. Ф. 400. Оп. 1. Д. 4548. Л. 1-15 об.Опубл: Восстание 1916 г22 fevralya 1917 g. Коріуа. RGVİA.F.400.op.1.D.4548.L.1-15 ob.

2. The Police-Director of Verni and Semireçe: The process of Turkestan from Russian domination to the uprising and the reasons and development of the rebellion, the information of the Consul of Kulca on the rebels who fled to China, the application of non-Russians to the Governor-General of Turkestan. report. Ноябрь 1916 г.РГИА. Ф. 1292. Оп. 1. Д. 1933А. Л. 475--505.; Noyabr 1916. RGIA. F. 1292. Op. 1. D. 1933A. L. 475-505.

3. The 12-page report of the Turkestan Region Committee explaining the mentality of the people in the region, the damages in the rebellion and the compensation of these losses, and the efforts to ensure the authority of the Russian state in the region. 27 июня 1917 г.РГИА. Ф. 1291. Оп. 84. Д. 57. Л. 2-13 .; 27 iyunya 1917 g. RGİA.F.1291.Op.84.D.57.L.2-13. 


\section{Giriş}

Çarlık Rusya’sının kolonist siyasetine uygun olarak Türkistan'a ilgisi Büyük Petro döneminde başladı. Büyük Petro ilgisini ispat edercesine Türkistan'a sefer yaptırdı. I.Petro'nun isteğiyle Türkistan'a iki sefer düzenledi. Bu seferlerden biri Sibirya tarafına, Küçük Buhara’ya diğeri ise Hazar tarafına Hive'ye yapıldı. Birinci seferin komutanlığını Buhgolts, ikincisi ise Preobrajen alayının komutanı knyez Bekoviç Çerkaskiy’e verildi. Knyez Bekoviç'in seferinin nedeni 29 Mayıs 1714'te senatoya Petro'nun verdiği raporda açıklanmıştı. Raporda şöyle yazıyordu: “Hive'ye tebrik amaçlı (bu dönemde Şirgaz yeni han olmuştur) heyet göndereceğiz ve aynı zamanda Buhara Hanlığına ticaret konusunu görüşmek için ve İrket şehri hakkında bilgi alarak Hazar denizi yakınlarında hangi nehirler olduğunu öğreneceğiz." $\mathrm{Bu}$ seferlerin amacı Sibirya yolu ile Çin'e, Türkistan yolu ile Hindistan'a ve Kafkaslar yolu ile İran ve Osmanlı Devleti’ne ulaşmak isteğiydi. Böylelikle Rus Çarı I. Petro Türkistan bölgesi üzerine emperyalist hedeflerle ilerleme fikrini ortaya atmış ilk Rus çarıdır. ${ }^{2}$ Yapılan seferler, onların bölgeyi daha yakından tanımaları, oralarda tahkimli bir hat inşa etmeleri, karakollar ve dayanak noktaları vücuda getirilmesi gibi kazançlar sağladi. ${ }^{3}$

Büyük Petro'nun Türkistan'a karşı ilgisini siyasi bir vasiyet gibi algılayan, ondan sonra Rus tahtına çıkan ardılları Petro’yu memnun etmek için yaklaşık 150 yıl sonra bölgeyi çarlık lehine işgal etti. Çarlık Rusya'sı, öne sürdüğü çeşitli nedenlerle Türkistan bölgesinde önce Kazak Cüzlerini ardından Türkistan hanlıklarını kullanageldikleri yanına alma, yalnızlaştırma ve bölme siyasetiyle 19. asrın son çeyreğine kadar işgal ve ilhak etti. ${ }^{4}$

Türkistan, Rus idari yapılanmasına uygun şekilde, “Туркестан генерал-губернатор/ Türkistan Genel Valiliğgi” olarak 11 Haziran 1867 'de teşkil edildi ${ }^{5}$ ve yönetimi genel valiye verildi. Türkistan ilk genel valisi General Konstantin Petroviç Кaufman (Константин Петрович Кауфман) 14.07,1867-04.05.1882 tarihleri arasında, son genel valisi ise Piyade Generali Aleksey Nikolayeviç Kuropatkin (General ot İnfanterii Алексей Николаевич Куропаткин)

1 M. Vyatkin, Oçerki po istorii Kazahskoy SSR: Top pervıy s drevneyşıh vremen po 1870, OGiZ: Gospolitizdat, 1941, s.90-91, Ayrıntılar için ayrıca bknz. Murat Özkan, "Petro'nun Altın Düşleri İvan Dmitrieviç Buhgolts'un Yarkend Keşif Seferi (1714-1716)", Hacettepe Türkiyat Araştırmaları Dergisi, 2020 Bahar (32), 187-202; Murat Özkan, "Bekoviç Gibi Kaybetmek: Aleksandr Bekoviç Çerkasskiy'in 1717 Hive Seferi" Marmara Türkiyat Araştırmaları Dergisi, 2018; V (1), s.93-111.

2 A.Zeki Velidi Togan, Umumi Türk Tarihine Giriş, Cild I En eski Devirden 16.Asra kadar 3.baskı, (İstanbul, 1981), s.152.

3 Akdes Nimet Kurat, Rusya Tarihi Başlangıçtan 1917'ye Kadar, (TTK Ankara, 2014), s.366.; Murat Özkan, "Bekoviç Gibi Kaybetmek: s.93-111.

4 M.A. Sarsambayev, kazakhskoye hastvo kak suvernoye gosudarstvo srednevekovoy epokhi, institut zakonadatelstva respuliki kazakhstan, (Astana, 2015), s.243-245; Baymirza Hayit, Türkistan Rusya ile Çin Arasinda,(Ankara, 1975), ss.23-45 historia rossi centralnaya aziya v sostave rossiysky imerii, novoye literaturnoye obozreniye, evropeyskiy universitet v (Saint-Petersburg, 2008), ss.33-39; Belyavskiy Nikolay Nikolayeviç, MaterialipoTurkestanu, (Saint-Petersburg 1885), s.34.

5 Nikolayeviç, Materialı po Turkestanu, s.34-35. 
22.07.1916 - 05.06.1917 tarihleri arasında görev yaptı. ${ }^{6}$ Çarlığın kolonist siyaseti sonucu olarak bölgede siyasi, askeri ve iktisadi sahalarda kendi lehine gücünü perçinlemek için 1867-1917 tarihleri arasında yasal düzenlemeler yaptı. Türkistan Genel Valiliğinin teşekkülü, bölgenin beş idari birimi Semireçe (Yedisu) Vilayeti, Sır Derya Vilayeti, Semerkand Vilayeti, Fergana Vilayeti Vilayetlerinden, Mavera-i Bahr-i Hazar (Hazar Denizi Ötesi) Vilayeti olarak bölmesi bu cümledendir. ${ }^{7}$

Batı Türkistan bölgesi I. Petro'dan itibaren Rusların en çok faaliyet gösterdiği bölgedir. Ruslar bölgeyi seyyahlar, tüccarlar, kendisine bağlı kossaklar, bölgeden Rusya'ya gidenler, bölgeye yapılan keşif seferleri nedeniyle tanımaktaydı. Bu nedenle bölge hakkında işgal öncesi ve sonrası çok ayrıntılı çalışmalar yapıldı. Bölgenin yer altı ve yer üstü kaynakları, dağları, madenleri, ovaları, nehir ve ırmakları, ekilebilir arazileri, nüfusu ${ }^{8}$ gibi konularda Ruslar bilgi sahibiydi. Bu bilgilere dayalı olarak Ruslar Türkistan bölgesinin tüm kaynaklarını sistematik olarak sömürmekteydi. Bu sömürü siyaseti yaklaşık 50 yıl devam etti. ${ }^{9}$

Çarlık Rusya’sının Türkistan’ı ele geçirmesi ile beraber bölgede yürüttüğü siyaset 1916 yılında çöktü. Aslında bu çöküş Çarlığın da çökmesinin yakın olduğunu gösteren işaretlerden biridir. Nitekim Rus Çarlığı devri 1917'de son bulacaktı. 19. Asrın ikinci yarısından sonra Türkistan’ı işgal eden Rusya'nın faaliyetleridir. Ruslar, Türkistan Bölgesi’nin hâkimiyetini elinde tutmak için buradaki Rus olmayan halkların yaşam alanlarına, yönetim biçimlerine, ekonomilerine, arazilerine ve hatta dini hayatlarına müdahalede bulundu. Mesela, Türkistan'da Rus kolonizasyonu, Rus idarecilerin taraflı yönetimi, mahkemelerdeki adaletsizlik, askerlikten muaf olan ahaliden alınan vergiler, Rus çarlığında Türkistan'da askerlikten muafiyet meselesi bu müdahalelerden bazılarıdır. ${ }^{10}$ Çarlık Rusya'sının müdahalelerine cevap, işgalden yaklaşık elli yıl sonra kendisini gösterdi. Türkistan' da gayr-1 Rus ahalinin bu elli yıllık dönemde baskıcı otoriteye karşı içlerinde biriktirdikleri kin ve bağımsızlık duygusu 1916 yılının Temmuz ayında ayaklanmalarla kendini gösterdi. ${ }^{11}$ Aynı yılın Ağustos ve Eylül aylarında ise ayaklanmalar isyana dönüştü ve zirveye çıktı. Çarlık hükümetinin bölgeye dair aldığı yeni kararlar bu duyguların patlamasına ve bölgedeki sessizliğin bozulmasına ortam hazırlayan sebeplerde sadece bir

6 Historia Rossii,s.424-42 5; M. Y. Şuşkova, Organizatsiya upravleniye Turkestanom v naçale XX veka, Dissertatsiya na soiskaniye uçenoy stepeni kandidata istoriçeskiy nauk, Rossiyskiy gosudarstvennıy gumaniternıy universitet, (Moskva, 2015), Ekler kismı Ek 6.

7 Piyade Binbaşı Nazmi Bey, Kafkasya ve Türkistan (Kafkasya, Asyâ-yıVustâ ve Türkistan Vilâyetleri Buhâra ve Hîve Hanlıkları Coğrafî, Siyasî, Tarihî ve İstâtistikî Mücmel Malûmât), (İstanbul Matbaa-i Askeriye 1918).

8 N.A. Maeva, Russkiy Turkestan sbornik, izdannıy popovodu politemniceskoyv istavki, VI ruskpervly, geografia i statistika, (podredakciyu Moskva v universitetskoytipograsiikatkov i k, 1872), ss.9-133.

9 Russkiy Turkestan sbornik, 1872, s.119. Ayıca bknz. Ayrıntılar için bknz. Dinçer Koç, “Buhara Hanlığı’na Gelen Rus Diplomat ve Askerler”, Türk Dünyası Araştırmaları, 2017, 115(227); Selim Serkan Ükten, “16-18. Asırlarda Buhara Hanlığı'na Gelen Batılı Seyyahlar ve Seyahatnameleri”, Eskişehir Osmangazi Üniversitesi Sosyal Bilimler Dergisi, 18(2), Aralık 2017, 137-164.; Murat Özkan, Türkistan’ın Keşif Çăğ, Kronik Kitap, İstanbul 2019.

1021 сентября 1915 г. АВПРИ. Ф. Среднеазиатскийстол. Оп. 486. Д. 340 б. Л. 5-5 об., С. 1-4, 8-13, 31-33; Sentyabrya 1915. AVPRİ. F. Sredne aziatskiystol. Op. 486. D. 360 b. L. 5-5 ob. S. 1-4, 8-13, 31-33.

11 Ayrıntılar için bknz. Seda Yılmaz Vurgun, “1916 Türkistan İsyanı”, Sutad, Güz 2016; (40), s.315-325. 
örnektir. Sonuçta ise Rusların 1867 yılından sonra başlayan Türkistan kadim ahalisinin aleyhine sürdürülen faaliyetlerinin etkileri Türkistan' da isyan ya da Ürkün katliamı da denilen olayların meydana gelmesine neden oldu. Çalışmamızı Türkistan bölgesi hakkında çarlığa ve çarlık sonrası geçici hükümete verilmesi için hazırlanan üç rapora dayalı olarak ele alacağız. Çalışmamıza kaynaklık eden üç rapor aşağıda maddeler halinde verilmiştir.

1. İsyanın başlaması, isyanın yayıldığı yerlerdeki maddi kayıplar, isyan sırasında alınan askeri tedbirler, isyandaki kayıplar, Türkistan isyanına katılanlara yapılacak muamele, isyan sonrasında Türkistan yönetimine dair Türkistan Genel Valisi Türkistan Bölge Askeri Komutanı'nın Çar'a sunulması için Harbiye Bakanlığı'na gönderdiği 15 sayfalık ayrıntılı rapor.

2. Verniy ve Semireçe Şehirleri Polis Müdürünün: Türkistan’ın Rus hâkimiyeti sürecinden başlayarak isyana kadar olan süreci ve isyanın nedenleri, gelişmesi, Kulca Konsolosunun Çin'e kaçan isyancılara dair bilgileri, Türkistan Genel valisine gayr-1 Rusların başvurusu gibi konuları ihtiva eden 30 sayfalık raporu.

3. Türkistan Bölgesi Komitesinin bölgedeki ahalinin düşünce yapısı, isyanda görülen zararlar ve bu zararların karşılanması, bölgede Rus devletinin otoritesini sağlamak için yapılacak olan çalışmaların ayrıntılı olarak anlatıldığı 12 sayfalık raporu.

Yukarıda bilgilerini ve künyelerini verdiğimiz söz konusu raporlarda, isyanın nedenleri, isyanın başlaması ve bölgede yayılması, isyandan etkileneler, isyan sonrası bölge yönetimine dair öneriler dikkate değer başlıklar olarak ön plana çıkmaktadır. Fakat bizim konumuzun kapsamını aştığından bu çalışmamızda raporlarda yer alan isyanın nedenleri ve isyanın başlamasına değineceğiz.

\section{Türkistan'da Millî Ayaklanmaya Giden Yol}

Çarlığın kolonist politikalarına karşı başlayan isyan, bir anlamda yaklaşık elli yıldır vesayeti altında bulunduğu Rus devletinin bölgedeki adaletsiz yönetim sisteminden kaynaklı gerginlik ve güçlüklerin bertaraf edilmesi amacına matuftu. Diğer yandan ise isyan, Türkistanlıların özgürlük savunmasında bulunmasının ete kemiğe bürünmesi olarak görülebilir.

\subsection{Jandarma Müdürü Capitan Rodmister V.F Jeleznyakov'un Raporu (Kasım 1916)}

Verniy ve Semireçe Şehirleri Jandarma Müdürü Capitan Rodmister V.F Jeleznyakov ${ }^{12}$ Semireçe vilayetindeki Kırgız isyanının nedenleri, gidişatı ve isyan sırasında insanların moralleri başlığı altında hazırladığı raporunu Kasım 1916'da Rus İçişleri Bakanlığına sunmuştu. Söz konusu raporda: Türkistan idaresinde Rus ve yabancıların ${ }^{13}$ Türkistanlılara davranışları, çarlığın bölgedeki Türkistanlılara ait arazileri gasp etmesi ve sosyal yaşama müdahalesi, Rusların

12 Jeleznyakov Vladimir Fedoroviç (02.01.1881-?). Orta Asya Demiryolları Jandarma Polis müdürü.

13 Ruslar kendisinden olmayanlar için bu tabiri kullanmaktadır. Bu yüzden Türkistanlılar da Ruslar tarafindan yabancı olarak adlandırılırdı 
oryantalist bakış açısı nedeniyle Rus ve yabacılar arasındaki çatışmalar, çarlığın bölgede aldığı yasal vergiler dışındaki ek malî talepleri, bölgede kurulan rüşvet ve tehdit çarkı, Çar II. Nikolay'ın 25 Haziran 1916 cephe gerisi işler için yabacıları orduya çağıran fermanı, dış güçler gibi işaret etmeye değer isyanın nedenlerine değinilmiştir.

Jeleznyakov: "Toplumda saygın"14 insanların fakirleri sürekli bir ekonomik baskı altında tutmaları onları kolayca yönetme şansı veriyordu. Bu yüzden yöneticiler onları yasal bir şekilde yağmalıyorlardl." düşüncesine sahipti. Jeleznyakov'un böyle düşünmesine sebep olan tecrübeleri vardı. Bu tecrübe ettiği yaşanmışlıkları raporunda:

"Halk mahkemesi, fakirlere zenginlerin istediği her şeyi yaptıran bir organdır. Ölüm dışında ve ă̆ır olaylar dışında kalan tüm konular bu halk mahkemelerinde görüşülürdü. Bu mahkemeleri üç yıllığına seçilmiş hâkim idare ediyordu. Kararlara karşı çıkış (temyiz) aynı volostta ${ }^{15}$ yapılıyordu. Mahkemeden çıkan ceza 1,5 yıl hapis cezası kadar olabiliyordu. Rus hâkimleri ve savcıları bu mahkemelere karlşmazdl. Bu mahkeme gücüyle, zenginler ve manaplar arasından seçilen hâkimler burayı elinde tutuyordu ve onlara tabi olmayanları suçsuz olsa bile cezalandırıyorlardı. Volost mahkemelerinin hâkimi üç yılda bir seçiliyordu ve üyeleri sadece zenginlerden oluşuyordu.$^{16}$ Ikki soy veya iki aşiret arasında bir volostta bu görev için mücadele olmazdl. Seçimlerde oy almak için rüşvet veriyorlardı. Bu seçim de ateşli konuşmalarla bazen de kavgalarla oluyordu. Kazaklar'da çoğu zaman zenginler bu seçimlere giderdi. Kara-Kırgızlar da ise bazen manaplar değil onların oyuncă̆ı olan insanlar giderdi. Seçimlerde çok para harcanırdl. Seçilenler oy veren kişilere para verirdi. Bazen bu para 10.000 rubleye ulaşlyordu. Göreve gelen kişi fakirlerden bu parayı yüksek faizle geri alıyordu. Mahkemelere yapılan şikâyetlere nadiren usule uygun şekilde bakılırdı. Her zengin veya manap ${ }^{17}$ kendi volost Kırgızlarının kaderi ve paralarıyla istediği gibi oynuyordu. Rus yöneticiler sadece manaplarla konuşurdu. Onların iç işlerine karışmazlardı. Yani Ruslarla ve yabanct yöneticiler arasında sessiz bir anlaşma vardı.

Rus yöneticiler bir şey istediğinde yabancı yöneticiler bu isteği kanunsuz bir şekilde yaparlardl. Örneğin; ĕger bir ev lazım olursa uyezd yöneticisi (Rus) volost yöneticisine (yabancl) söylerdi. $O$ ise bir aileyi evinden çıkarıp onları dışarda bırakarak bu işi çözerdi. O eve gelen Rus yöneticiler için koyun kesilir, o koyun da bir Kırgız'ın elinden alınırdı. İzinsiz bir şekilde gelen Rus yöneticiye harcanan para onun rütbesine göre değişiyordu. ${ }^{18} 10$ rubleden 300 rubleye kadar harcama miktarı değişebiliyordu. Misafir yönetici ya da memur gittikten sonra volost yöneticisi, harcanan parayl yasaklar (vergi) vasitasiyla onlardan alırdl. Bazen bu masraf iki katı kadar olabilirdi. Yapılan bu masrafları eşit şekilde her çadır sahibine paylaştırırdı. Bu parayı gerçekten harcayan kişiye ödemezdi. Parayı kendine alırdı. Bir kısmını ise diğer memurlarla paylaşırdl. Halk mahkemesi köy büyüğ̈̈ ile ve diğer önderler bu kanunsuz para

14 Devlet idaresinde yetkili olan kişiler için kullanılan tabir.

15 Volost (Волост):1917 Ekim devrimine kadar çarlık ve SSCB'nin 30'lu yıllarına, rayonlaştırma yapılan kadarki süre zarfında uyezdin bir kısmı olarak sayılan alt seviyedeki yönetimsel birime verilen addır.

16 Ноябрь 1916 г. РГИА. Ф. 1292. Оп. 1. Д. 1933А. Л. 475-505.; Noyabr 1916. g. RGİA. F. 1292. Op. 1. D. 1933A. L. 475-505. s.10.

17 Manap, Kirgız toplumunun varlıklı sosyal sinıfina ait kimselere denir.

18 Ноябрь 1916 г.РГИА. Ф. 1292. Оп. 1. Д. 1933А. Л. 475-505.;Noyabr 1916. RGİA. F. 1292. Op. 1. D. 1933 A. L. 475-505. s.8. 
toplamaya "Çigan” adı veriyorlardı. İlk başlarda çigan harcamaları azdı; çünkü burada Rus yöneticileri sayısı çok değildi. Sonradan buraya gelen yeni Rus memurlar Kırgızların misafirperverliğini suiistimal ettiler. Bunlar yiyecek içeceklerini Kırgız yöneticilerden değil direk Kırgız halktan istiyorlardı. Bazen halkla çatışmaları bile olurdu. Bu misafirlik durumunu en çok suiistimal eden küçük rütbeli Rus memurlarıyd. Yiyecek ve içecek fiyatlarında da olan artış çigan harcamaları daha da arttırdı. Bir koyunun fiyatı üç ile dört rubleden 15 ile 20 rublye kadar yükselmişti. Bazı Rus memurlardan duyuyordum ki Kırgızlar misafir kabul ettiğinde para almak istemiyorlarmış, bu onların kültürlerine uygun değilmiş biz istemeden orada kalıyoruz; çünkü Kırgızların evinden başka orada kalacak yerimiz yoktur. Kendi tecrübemden biliyorum ki bu bir yalan ben oraya gittiğimde ve Kirgız evinde, yurdunda kaldı̆̆ımda yaptı̆̆ım tüm harcamaların karşılı̆̆ını evin sahibine ödüyordum. Bölgede bulunan diğer memurlardan daha üst görevde olduğum halde ben ödemeleri yapıyordum. Ĕger bu parayı Kirgızlar almasalardı benden almazlardı. ${ }^{19}$ ",

satırlarıyla Rus memurların yabancılara ve yabancı yöneticilere davranışını örnek ve ayrıntılarıyla raporda anlatarak yaşananları isyanın nedenlerinden bir tanesi olarak göstermektedir.

Raporda geçen bir diğer isyan nedeni şu şekilde kayıtlıdır:

“1906-1907 yılında çıkan tarım sorunu, Avrupa Rusya sında büyük bir göç ile sonuçlandı. Büyük sayıda insanı bölgelere yerleştirmek gerekiyordu. Bu bölgeler arasında Semireçe oblastı da vardı. Rus yöneticiler bölgede arazi ayarlama çabalarına girdiler. Kırgızların fazladan denilen topraklarını onların ellerinden almaya başladılar. Belki de bu fazladan topraklar gerçekten de vardı. Bu toprakları almadan önce Kırgızların yerleşik hayata geçmesi gerekiyordu. Ama Kırgızlar göçebe hayatı sürdürdükleri için hayvancılıkla uğraşıyorlardı. Kırgızlara verilen topraklar onlar için az ve Kırgızlara yetmiyordu. Göç dairesinin yanlış işlerinden biri de Kırgızların topraklarına önem vermemesiydi. Kırgızların göçebe hayattan yerleşik hayata geçişleri planlı bir şekilde yapılmıyordu. Bu geçişin sistematik bir şekilde yapılması gerekiyordu. Zengin Kırgızlarla mücadele edilmeli; ama buna karşın hayvanı olmayan kişiler yerleşik hayata geçmeyi kabul ederdi. Yerleşik hayata geçmek için tüm volostun oyu gerekiyordu. Bu da imkânsızd. Çünkü buradaki zenginler bunu istemiyordu. Göç idaresinin yaptı̆̆ iş̧ler yabancıların normal hayatını değiştirdi. Göç ettirilenlere verilen toprakların içine Kırgızların kışlak topraklarının bir kısmı da eklendi. Bu yüzden Kırgızlar ise dağ taraflarına çekilmek zorunda kaldılar. Yaz otlaklarl "caylyau" adı verilen ve ormanlık bir yerde bulunan yerler, Orman Bakanlı̆̆ tarafindan ormanları korumak amacıyla Kırgızlardan alındı. Kışlık ve yaylak arasındaki yol üzerinde bulunan Ruslar da bunların işlerini zorlaştırıyordu. Göç işleri başladığından beri yedi yılda Kırgızların klşlaklart iki ile üç kez değişti. ${ }^{20 "}$

Çarlığın Türkistanlıların elinden aldığı ya da gasp ettiği arazileri ve sosyal yaşama müdahalesini Jandarma müdürü isyanın ikinci nedeni olarak göstermektedir.

19 Ноябрь 1916 г. РГИА. Ф. 1292. Оп. 1. Д. 1933А. Л. 475-505.; Noyabr 1916. RGİA. F. 1292. Op. 1. D. 1933 A. L. 475-505. s.9.

20 Ноябрь 1916 г. РГИА. Ф. 1292. Оп. 1. Д. 1933А. Л. 475-505.; Noyabr 1916. g. RGİA. F. 1292. Op. 1. D. 1933A. L. 475-505. s. 10. 
Rusların Türkistanlılara oryantalist bakışı ve iki halk arasındaki çatışma, raporda isyanın başka bir nedeni olarak öne sürülmektedir. Polis müdürü bu nedeni şu sözlerle anlatmaktadır:

"Avrupa Rusya 'sında tarım sorunu oluştuğunda herkes Semireçe bölgesine göç etmeye başlad. Çünkü burada gelenlere ücretsiz toprak veriliyordu. Göç eden kişiler burada yaşayan kişilere istedikleri şekilde davranmalart yabancılarla onları düşman haline getiriyordu. Yeni gelen göçmenlerin buradaki yabancılar için köpek slfatıyla hitap ediyorlardl. Onlara köpekmiş gibi davranıyorlardı. Kırgızların gelirlerini araştırmaya başladılar. Kırgızların meraları göç edenlerin geldiği yerlere yakındı. Buraya göç eden Ruslar, yabancıların hayvanlarını çalıyorlardı. Çobanlardan ise hayvanlarını alıp onu köyden kovuyorlardı. Bu hayvanı istemeye gelen Kirgızlara ise bu hayvan bizim topraklarımızdan ot yemiş, bu ot karşılığında her bir hayvan için 1- 3 ruble vereceksiniz diyorlardı. Kırgızlar yaylaklardan döndügü̈nde mecburen buraya göçle yerleşen Rus köylerinden geçiyorlardı. Bu durum Ruslarla yabancılar arasındaki ilişkileri gerginleştiriyordu. Az da olsa çobanlar bilerek onların arazilerinden geçiyorlardı bu durumla çok karşılaşmadık. Kırgızlar mahkemeye, bu durumu şikâyet etmiyorlardı. Etseler bile bu bir sonuç vermiyordu. Yöneticilerin burada az olması, onların zamanın olmaması ve böyle işlerle uğraşmak istemediklerini bilen Kırgızlar bu hayvanların yediği ot için "Patrava" adı altında Ruslara para veriyor ve olayı büyütmek istemiyorlardl. Buraya yerleşen Ruslar şöyle diyorlardl: "bize her şeyin verilmesi gerekiyor yabancılar bir köpektir onlara güzel davranmak gerekmiyor." Yabancı Kirgizlara Rusların bu tür davranışları eskiden onlarla iyi komşuluk ilişkisi içinde yaşayan Rus Kazaklarını da etkiledi. Onlar da Kırgızlara karşı yavaş yavaş saygısızca davranmaya başladılar. Kırgızlar bu yapılanların hepsini görüyordu; ama kinlerini içlerinde sakllyorlardl. ${ }^{21}$ Burada Rusların Tarançin ve Dunganlara karşı davranışlarıyla Kırgızlara davranışı arasında büyük bir fark vardl. Yeni gelen Ruslar Tarançin ve Dunganlara tartışmaya girmekten korkuyorlard. Çünkü bunlar Ruslara çok sert bir tepki gösteriyorlardl. Kırgızlar ise ağlamak ve şikâyet etmekten başka bir şey yapamiyorlardı."

Rusların Kırgızlara karşı bu davranışı rapora göre isyanın üçüncü nedenidir. Rusların Türkistanlılara küçültücü, aşağılayıcı davranışları Kırgızlar içerisinde kin olarak birikmişti.

Çarlığın yaşadığı siyasal gelişmelere bağlı olarak (I. Dünya Savaşı gibi), söz konusu bölge ahalisinden yasal vergiler dışında ek maddi yardım talepleri gelmekteydi. Çarlığın bu talepleri aşağıdaki gibi açıklanmıştır:

"Rus-Japon Savaşı 1905 yılında başladığında Kırgızların yardım etmelerini Rus yöneticiler istediler. Battaniye, para, çadır, yoğurt, çorap ve benzeri yardımlar talep ettiler; ama sonradan bu yardımlar Kırgızlardan zorla alınmaya başlandı. Bu durum gasp haline gelmeye başlamıştı. Bu yardımların kökten yanlış olduğunu düşünüyorum. Her uyezd $d^{22}$ müdürü birbiri ile yarışa girerek üst yöneticilerin gözüne girmek için daha çok yardım götürme yarlşı içindeydi. Bu yardım toplamaları zenginler ve manaplar vasıtasıyla oluyordu. Bu iş büyük bir ölçüde

21 Ноябрь 1916 г. РГИА. Ф. 1292. Оп. 1. Д. 1933А. Л. 475-505.; Noyabr 1916. g. RGİA. F. 1292. Op. 1. D. 1933A. L. 475-505. s.11.

22 Uyezd (уезд): Çarlık Rusyasında ve 1929'a kadar SSCB'de birkaç vilayetin birleşiminden oluşan idarî birim. 
şu şekilde yapıllyordu. Kırgızlara sürekli "siz savaşa gitmiyorsunuz sizin yardım etmeniz gerekiyor." sözleri söylenmekteydi. Bu yardımlar fakir Kırglzlardan zengin ve manaplar tarafindan zorla alınıyordu. Bunlar fakir Kırgızlardan aldıkları yardımların bir kısmını kendilerine sakliyorlardı. Oblast ${ }^{23}$ yöneticileri gerçekten bu yardımın Kırgızların gönüllü olarak yaptıklarını düşünüyorlardı ya da buna böyle inanmak istiyorlardı."

Polis müdürü yukarıdaki sözleriyle bu olayların Kırgızların nefretinin artmasına yol açtığına dikkat çekmiştir. Raporda bu durum isyanın dördüncü nedeni olarak ele alınmaktadır.

Türkistanlılar hem çarlık hem de çarlığın hizmetkârı olan Rus memurlar tarafindan adeta soyuluyordu. Jeleznyakov raporunun bu kısmında bölgede yapılan soygun ve rüşvet çarkının tarafları hakkında düşüncelerini şu şekilde anlatmıştır:

"Yöneticiler buradaki kulaklara" yani buradaki zenginler ve manapların bunlara karşı samimi olduklarına inaniyorlardl. Çünkü buna inanmak işlerine geliyordu. 2. Verniy Polis müdürü görevine Protikov geldiğinde 25 (gerçekten de bu adam çok zeki bir adamdi) buradaki Müslümanlarla görüşmeye başladı. Son yıllarda ise Kırgızlar ile görüşmeye başladı. Bu sistem şöyleydi yakın bir adamının (Namangan Sartı Zakir Ísabayev'di) yardımılla işlerini yürütürdü. İsabayev'in hiçbir resmi görevi yoktu. Protikov tüm başıboş gezen yabancıları ve oblastı gezerek onlara "jandar" ismini vererek yabancı ahaliden zorla para ve mal alıyordu. Jandar sözü kazıkçı sözüyle aynı anlama geliyordu ve bu jandarlar tüm yabancıların korkusu haline gelmişti. Çünkü bunlar bir yabancı hakkında şikâyetçi olursa, bu durum yabancının hapse atılması ile sonuçlanabilirdi. Polis müdürü Türkistan Genel Valisi Folbaum'un o kadar güvenini kazanmıştı ki tek sözü bile yabancının hapse atılmasına yeterdi. Bu jandarlar İsabayev ve Proitikov'un tüm işlerini yapıyorlardl. Jandarlar karşısında korku o kadar büyüdü ki zengin adamlar ve manaplar bile onlardan çekiniyordu. Jandarların faaliyeti hakkında ben daha önceki ölen valiye ve hâkimler meclisi savcısına en son 2. Verniy'ye geldiğimde durumu bildirmiştim. Ama Protikov'un valiye etkisi o kadar fazlaydı ki benim söylediklerim tesir etmiyordu. Jandarların yaptıklarını valiye, savcıya ve 2. Verniy uyezd müdürü Lihanov'da bildirmiştim."

Bu anlatım, Türkistanlılar için hayatın yaşanmaz hale getirilmesine bir örnektir. Polis müdürünün de değindiği gibi Jandarların kanunsuz eylemleri, Kırgızların Ruslara karşı kin beslemesine yol açmış, bu durum da raporda isyanın beşinci sebebi olarak sayılmıştır.

Jeleznyakov raporda hem Türkistan Genel Valisi Kuropatkin'in hem de yardımcısı General Erofeev'in başkent Petrograd'a isyanda dış güçlerin varlığı iddialarını şu kanıtlarla çürütmüştür:

23 Oblast(Bölge) Yönetimi: Yönetimsel, mahkeme(yargı) ve ekonomi olarak üç kısımdan oluşuyordu. Bu kısımlar askeri valinin aldığı kararların doğruluğunu inceliyordu. Aynı zamanda askeri valinin yardımcılarıyla beraber hareket ediyorlardı. Oblast yöneticisini yetkisi gubernaya yöneticisi yetkisine ve hazine işlerindeki sorumluğunun aynısına sahiptir.

24 Çarlığa tabii olanlara verilen ad. İtaatlik göstergesi anlamında da kullanılır.

25 Ноябрь 1916 г. РГИА. Ф. 1292. Оп. 1. Д. 1933А. Л. 475-505.; Noyabr 1916. g. RGİA. F. 1292. Op. 1. D. 1933A. L. 475-505. s. 12. 
İsyanin nedeni ve akışı bu raporumun sonuna ek olarak bölgede Alman propagandası var mıydı? sorusuna yönelik şöyle cevap vermek istiyorum: Böyle bir propaganda yoktu. Bunun olduğunu kanitlamak isteyenler kendi yaptıkları cinayetleri örtmek istiyorlar. Novovremya yani Yeni Zaman Gazetesi'nin 14.596. numaral 23 Ekim sayısında "Çin Türkistan'ında Almanlar" adll yazı vardı. Bu yazının içeriği şöyleydi: Şanhay Dergisi "The Clestial Empire" "Gö̧̧ Imparatorluğu” Alman ve Türk ajanlarının Çin eyaleti Sinzen'de Çin Türkistan ' faaliyetleri hakkında yazıyordu. Alman ve Türk propagandistleri Çin'e Iran ve Afganistan'dan geçerek ${ }^{26}$ burada yaşayan Müslümanların arasında isyana klşkırtılması ve bu isyanın Rus sınırına geçmesi, böylelikle Rusya ile Çin arasında sürtüşmelerin olduğunu gösterme düşüncesinden yazlyorlardl. Rus ve Ingiliz hükümetleri Çin'i Alman ve Türk propagandistlerin tehlikesine karşı uyarmıștı. Yakalanan bazı ajanlar da Doğu Türkistan'a giderken üzerlerinde Türk Sultanın imzasıyla ve Enver Paşa'nın cihat çağrısı ile ilgili bildiriler bulundu. Ajanlar aynı şekilde Kalgan ve Yarkent'te de yakalanmış ve Almanya konsolosluğuna teslim edilmişlerdir. Büyük ihtimal konsolos onları serbest bırakmış ve onlar işlerine devam etmişlerdir. Son Alman entrikalarının şahidi, Pekin'deki Alman konsolosluğunda ateşe görevinde bulunan Doktor Hentiga von Hentig idi. Iran üzerinden Pekin yoluyla Çin Türkistan'ına gelmişti. Kaşgar konsolosluğunun gizli mektuplarında yazan bilgiler bunları doğrulamaktadır. Ama Albay Hentig yabancıların isyanına hiçbir etkide bulunmadı. Çin topluluğu olan Ge Lao Huy hakkında 1Şubat-1 Eylül arasında benzer bilgiler vardı.".

Jeleznyakov raporuna ek olarak Türkistan Genel Valiliğinden aşağıda verdiğimiz bazı isteklerde bulunmuştu:

\begin{abstract}
"Şuan oblasttaki durum şöyledir:
1. Yabancı Ahali: yabancı ahali askeri işlere işçi göndermek için işçi partileri oluşturuyor ve hiçbir sıkıntı yaşanmıyor. ${ }^{27}$ Kırgızların moralleri çok kötü. Çünkü Rus Kazakları ve Rus ahali, isyanı bastırma çalışmalarının yanında Kırgızların evlerini de yağmaladılar. Hiçbir suçu olmayan Kırgızların yurtlarını ve kışlaklarını dağıtmışlar ve yakmışlardır. Bunların birçoğu evsiz ve hayvansız kalmıştır. Büyük ihtimal ileride bunlar eşklya da olabilirler.

2. Stanitsalarda yaşayan Rus Kazakları. Mesela, Kaskelen stanitsasında, Calanaş stanitsası ve Nikoloyev stanitsası yakınındaki birçok Kırgız'ın malını çalmışlar. Samsonov stanitsasının Rus Kazakları ise birçok Kırgız'ın malını yağmalamıştır.

3. Tokmak rayonu ve Pispek uyezdi köylüleri hayvansız kalmışlardı. İsyancılar tarafindan bu hayvanlar çalınmıştır. Tüm oblastta Prejeval uyezdi ve Tokmak rayonunun bir kısmı dışında tarladaki buğday toplanmışt. Prejeval de buğday tamamen toplanmamış ve insanlar çok kötü durumdadır. Onlara acil yardım etmemiz gerekiyor. Bunu bana Prejeval'deki bir yüzbaşı rodmister yazdı. Tokmak'daki köylüler Kırgızlara ait buğdayları topladıkları için buğdaya ihtiyaçlarl yoktur.

4. Şehirlerde buğdayın birkaç kişinin eline geçmesinden dolayı tüm şehirde buğday çok azdır. Bu buğdaylar birkaç kişi tarafindan alınmıştır. Zengin Rus Kazakları ise şehirlere
\end{abstract}

26 Ноябрь 1916 г.РГИА. Ф. 1292. Оп. 1. Д. 1933А. Л. 475-505.; Noyabr 1916. RGİA. F. 1292. Op. 1. D. 1933 A. L. 475-505. s.30.

27 Ноябрь 1916 г. РГИА. Ф. 1292. Оп. 1. Д. 1933А. Л. 475-505.; Noyabr 1916. g. RGİA. F. 1292. Op. 1. D. 1933A. L. 475-505. s.31. 
buğday getirmiyorlar, fiyatın yükselmesini bekliyorlardı. Bunların böyle bir durumda olduğunu gördüğ̈̈mde ben Şubatta zenginlerin elindeki buğday stoklarının listesini hazırladım ve bilgi aldım 23 Şubat 116 numaralı mektubumda bunu bildirmiştim. Bu buğdayı ellerinde bulunduran karaborsacılarla mücadele edilemiyor ve fiyatlar yükseliyordu. İhracat yok stoklar çok olmasına rağmen. Halk, hükümetin bu konuya müdahale etmemesine tepki gösteriyordu. Yakacak odun fiyatları dört kat yükseldi. Büyük ihtimal bu fiyatların yükselişi ayaklanmalara neden olabilirdi. Yerli tüccarlar üretim malların özellikle son günlerde belli ki fiyatları yükseltmişlerdi. ${ }^{28}$ Fiyat yükseltilmesi olayı, bölgeye Tatar iş adamı Zaynuddin Tazedinov'un gelmesiyle başladı. Ben onu Panislamizm düşüncesini yaydiğı için 2. Verniy hapishanesine attım (8 Haziran 3150 numaralı bildiri). Zaynuddin Tazedinov büyük bir iş adamıydı. Aynı zamanda "Gabduleyevlerin” ticarethanesinde yöneticiydi. Semireçe bölgesi üretim mallarının piyasasını elinde tutuyordu. Bunların fiyatları yükseltmeleri, yerli halk arasında Tazedinov ve Gabduleyevlerin yă̆malanması ve mallarının yakılması olaylarına neden oldu. Mecliste bu işi önemsemediler. Daha önce yăgmalanmış olan ahali bunun suçlusu olarak yerel ve merkezi yöneticilerin tepkisizliğini görüyor ve böyle yaparak isyana izin verdiklerini düşünüyorlardı. Şimdi ise isyandan zarar görenlere yardım etmiyorlar diye şikâyet ediyorlar. En fazla tepkiyi ise ölen eski valiye göstermişlerdi. Şuan bile birçok kişi valinin öldüğüne inanamıyor, onun için kaçtığını söylüyorlardı. Buradaki takviye askeri birliklerinin bölgeden çıkması üzerine bölge yeniden karışacaktır. Ama ne kadar karışacă̆ını bilemiyoruz. 5. Zenginler burada dengelerin değişmesinden, ellerindeki gücün gitmesinden korkuyorlar. Tarım Bakanlı̆̆l ve Iç Işsleri Bakanlı̆̆ı'nın arasındaki mücadeleyi gerekçe olarak gösteriyorlar; ama bu lafta kalıyordu.

6. Bölgede bir devrim düşüncesi yok. Ama insanların morali çok bozuk. Rusların yabancılara yabancıların ise Ruslara karşı bir nefreti var. Hem yabancılar hem de Ruslar yönetime karşı tepkilerini gösteriyorlar. Buradaki oblast yönetimini değiştirmek gerekiyor; çünkü askeri yönetim kendi menfaatlerine uygun davranarak bölgeyi normal hayatın gerisine düşürmüş̧ı̈. Buraya göç siyasetini de kökten değiştirmek lazım. ${ }^{29}$ Buradaki Kırgızların ilk başta yerleşik hayata geçmeleri sağlanmalıdır. Yöneticileri soruşturmak, içindeki hırsızları görevden almak ve Kırgız ahalisinin yönetim şeklini değiştirmek gerekiyor. ${ }^{30}$,

Yukarıdaki maddelerle oblasta dair tespit, görüş ve önerilerini Jandarma Müdürü Capitan Rodmister V.F Jeleznyakov, genel valiye ve İç İşleri Bakanlığına sunmuştur.

28 Ноябрь 1916 г. РГИА. Ф. 1292. Оп. 1. Д. 1933А. Л. 475-505.; Noyabr 1916. g. RGİA. F. 1292. Op. 1. D. 1933A. L. 475-505. s.32.

29 Ноябрь 1916 г. РГИА. Ф. 1292. Оп. 1. Д. 1933А. Л. 475-505.; Noyabr 1916. g. RGİA. F. 1292. Op. 1. D. 1933A. L. 475-505. s.33.

30 Ноябрь 1916 г. РГИА. Ф. 1292. Оп. 1. Д. 1933А. Л. 475-505.; Noyabr 1916. g. RGİA. F. 1292. Op. 1. D. 1933A. L. 475-505. s.34. Bu raporun 34. sayfasından başlayarak 42. sayfaya kadar Doğu Türkistan'daki Çin Hükümetinin faaliyetlerini içermektedir. 


\subsection{Türkistan Son Genel Valisi Türkistan Bölge Askeri Komutanı Aleksey Nikolayeviç Kuropatkin Raporu (20 Şubat 1917)}

Türkistan Genel Valisi, Türkistan Bölge Askerî Komutanı Aleksey Nikolayeviç Kuropatkin ${ }^{31}$ Çarlığa sunulması için 22 Şubat 1917'de bölgedeki görev süresince yaptığı faaliyetleri ihtiva eden bir rapor hazırladı. Söz konusu raporda, Türkistan bölgesindeki yabancıların işe alınma emri, 28 Haziran 1916'da İç İşleri Bakanlığı'nın 18991 numaralı telgrafi ile Kuropatkin'e bildirildiği bilgisi yer almaktadır. Bu bildiri, yerleşik ve göçebe hayat süren yabancılar arasında ayaklanmaya neden oldu. Rapora göre isyanın birinci nedeni, orduda cephe gerisinde yani istihkâm mevkiinde 25 Haziran 1916 tarihinde Çar Nikolay’ın fermanı ile Türkistan bölgesindeki gayr-1 Rusların askere çağrılmasıdır. ${ }^{32}$

Türkistan son genel valisi Kuropatkin ayrıca isyanın diğer sebeplerini raporunda "Türkistan Bölgesindeki İsyanların En Önemli Nedenleri” başlığı altında yazmıştı. Raporda yer alan isyan nedenleri;

1. İsyanın en önemli nedeni, 25 Haziran fermanını hemen açıklamamı oldu. Bu durum bizi de ahaliyi de zor durumda bıraktı. Türkistan'daki ahalinin nüfus kaydı ve yaşları belli olmadiğı için 19 ile 31 yaş arasındaki erkeklerin işe alımı bizi zor bir duruma soktu. ${ }^{33}$ En önemli iş gücünün alınmasından dolayı tarlalardaki ekinin toplanamaması, bölgeyi zor durumda bıraktı. Dedikodular ahali içinde yayıldi. En korkunç dedikodu da yabancıları savaşa götüreceğimizdi. Ahali, onları önce cephede çalıştıracağımızı ve öleceklerini düşünmüştü. Topraklarını Ruslara vermek için onları böyle kullanacağımızı düşünmüşlerdir.

2. Yabancılar arasında dış güçlerin de propagandası yapılıyordu. Buna örnek, Cizak uyezdi isyanlarının Ruslara zarar verdiği zaman biz Ruslarla değil, Almanlarla birlikte yaşamak istiyoruz, bunun için bize Afganistan yardım edecektir demeleriydi.

3. Cizak uyezdi Bogdan bölgesinde yaşayan eski Çarderin Bek'inin oğlu Cevaş Abducavarov, Cizak beyi seçildi ve Cizak'ı ele geçirmek için yürüyüs yaptı. Sanzar'da ise Turakul Turdabekov diye birisi Sanzar beyi ilan edildi. Cizak uyezdinin Zamin bölgesinde ise İşan Kasım Hoca Zamin Beyi seçildi. Yabancıların elinde olan esirlerin anlattığına göre bunlara Alman ve Türk ajanları da yardım ediyorlardı.

4. 1887 yılında Türkistan bölgesi yönetim kurullarını beğenmemeleriydi. Yabancılara karşı Rus yöneticilerin kaygısı yoktu. Uyezd müdürü bunları yaşadıkları bölgeden uzaklaşstırdı. Ahalinin tüm yetkisi yabancı yöneticilerin eline geçti. Bunlar büyük güç kazandılar, başa seçimlerle değil atamayla gelmişlerdir. Bu yabancı yöneticiler sanki eski Bek yönetimini

31 Kuropatkin Aleksey Nikolayeviç (17.03.1848 - 16.01.1925)Askeri Bakan (01.07.1898). Mançurya Ordu Komutanı (07.02.1904) Japonya savaşında ordu komutanı (13.10.1904). Türkistan Genel Valisi, Türkistan Askeri Bölgesi Birlikleri Komutanı ve Semirechensk Kazak Ordusu Askeri Düzeni Ataman (22.07.1916). Muhammet Şen-Ferdi Çiftçioğlu, “Türkistan Genel Valisi Aleksey Nikolayeviç Kuropatkin'in Türkistan İzlenimleri (1916)", Akademik Tarih ve Düşünce Dergisi, 2018 5(17), s.187.; Serkan Yazıcı -M. Bilal Çelik, “Türk Tarihinde Bir Rus General: Aleksey Nikolayeviç Kuropatkin(1848-1925)", Sakarya Üniversitesi, Fen Edebiyat Dergisi 2008, s.141-142.

3222 февраля 1917 г. Копия. РГВИА. Ф. 400. Оп. 1. Д. 4548. Л. 1-15 об. Опубл: Восстание 1916 г. 22 fevralya 1917 g. Kopiya. RGVİA. F. 400. op. 1. D. 4548 . L.1-15 ob. s.1.

3322 февраля 1917 г. Копия. РГВИА. Ф. 400. Оп. 1. Д. 4548. Л. 1-15 об. Опубл: Восстание 1916 г. 22 fevralya 1917 g. Kopiya. RGVİA. F. 400. op. 1. D. 4548 . L.1-15 ob. s.8. 
getirdiler. Halk mahkemelerinde haksızlık yapılıyordu. Zakapinskiy Bölgesi dışındaki tüm bölgeler bu durumdan memnun değildi. Büyük emri uyguladıkları zaman buradaki uyezd müdürleri ve polisleri liste oluşturmaya başladılar. ${ }^{34}$ Ayaklanmalar da bu yüzden çıktı. Böylece yabanc yöneticilerden ahali intikam almaya başladı. 7 volost yöneticisi, 6 volost sekreteri ve bunların on tane korumaları öldürülmüştür. Volost yöneticileri arasında Rusya'ya sadık olanlar da vardı. Bunlardan Rus ahaliyi ve posta istasyonlarını korumaya çalışanlar da mevcuttu. Rus yöneticilerin arasında çok tecrübeli olanlar da bulunmaktaydı. Onlar, isyanı durdurmak için olumlu işler yaptılar ve hala da yapıyorlar.

5. Buradaki polis sayısı yeterli olmadığından bu ayaklanmalar engellenemedi. Yöneticilerin sayısı da yeterli değildir. Onlar bu emri nasıl söyleyeceklerini, nasıl anlatacaklarını bilemiyorlardı.

6. Bazı memurlar volostaki işleri takip etmiyorlardı. Halk mahkemelerinin ve yabancıların dinî hayatını takip etmiyorlardı.

7. Bundan başka size bildirmek istiyorum ki 30 yıldır bazı yabancı gruplar arasında Ruslara karşı kin vardır bunun nedeni ise şudur:

Pamuğun gelişmesi ile özellikle Fergana bölgesinde büyük paralar dönmeye başladi. Zengin yabancılar grubu ortaya çıtı. Gelişen bu ticaret sayesinde küçük toprak sahiplerinin işleri kötüye gitmeye başladı. Onlar borçlanarak topraklarını kaybetmeye; Zenginler de, bunların topraklarını almaya başladılar. Yabancı Yahudiler de toprakları alarak topraksız insan sayısını arttırıyorlardı. Ahali borçlanmaya başladı. Bilgilere göre bir tek Fergana oblastında mahkeme kayıtlarına göre 1914-1915 yıllarında ahalinin 16 milyon ruble borçlu olduğunu görüyoruz. Küçük çiftçilerin küçük toprakları bile ellerinde kalsın diye devlet bu küçük çiftçileri korumadı. ${ }^{35}$ Bu borçlulara hiçbir hakkı verilmiyordu. Hemen borçlarını ödemeleri isteniyordu. Borçları karşılığında her şeylerini satıyorlardı. Volost büyükleri ve hâkimleri (kadıları) birçok olayda zenginleri tutuyorlardı. Fakirleşen bu üç bölge kendi yabancı yöneticilerini ve hâkimlerini sevmiyorlardı. O yüzden isyan zamanı ilk olarak bunlara saldırdılar. Ahalinin bir kısmının zengin olması ve bunların içki içip kumar oynamaları ve kadınlarla eğlenmeleri, yabancı din adamları ve yaşlılar arasında Rus Hükümetine karşı bir kin oluşturmaya başladı.

[Raporda Kırgız. Ahali hakkında:] Türkistan bölgesinde yaşayan diğer halk nüfusu 2.615 kişi bunların topraklarının bölünmesinde haksızlı̆̆a uğradıklarını düşünüyorlardı. Göçebe hayatı süren Kırgızların göç ettikleri topraklar artık devlet arazisi sayılmaya başlandi. 1904 yılından itibaren bu toprakların çok olması ve Kırgızlardan büyük toprakların alımı, burada Rus köylerinin kurulması ve bu toprakların Kırgızlar için çok önemli olması ayaklanmaların bir nedeniydi. Bunu daha önce Grafpalena söylese de onun sözlerine kimse önem vermemiştir. Kırgızların geride kalan topraklarında ise, orman bekçileri tarafindan sürekli sıkıştırılmaktaydılar. Bu bekçiliği fazla kontrol etmediğimizden onlar istediğini yapıyorlardı. Tüm oblastlardan bana şikâyetler geliyordu. Bekçilerin müdürleri bu durumu onaylıyordu. Ama işçinin az olmasından dolayı bunu durduramıyorlardı. ${ }^{36}$ Bundan başka Kırgızlar volost yöneticilerinden ve halk mahkemelerinin icraatlarından da memnun değillerdi.

3422 февраля 1917 г. Копия. РГВИА. Ф. 400. Оп. 1. Д. 4548. Л. 1-15 об. Опубл: Восстание 1916 г. 22 fevralya 1917 g. Kopiya. RGVİA. F. 400. op. 1. D. 4548 . L.1-15 ob. s.9.

3522 февраля 1917 г. Копия. РГВИА. Ф. 400. Оп. 1. Д. 4548. Л. 1-15 об. Опубл: Восстание 1916 г. 22 fevralya 1917 g. Kopiya. RGVİA. F. 400. op. 1. D. 4548. L.1-15 ob. s.10.

3622 февраля 1917 г. Копия. РГВИА. Ф. 400. Оп. 1. Д. 4548. Л. 1-15 об. Опубл: Восстание 1916 г. 22 fevralya 1917 g. Kopiya. RGVİA. F. 400. op. 1. D. 4548. L.1-15 ob. s.8. s.11. 


\begin{abstract}
[Türkmen Ahali]: Türkmenlerin büyük kısmını Tekinler oluşturuyordu. Onlar isyan zamanı sessiz kaldılar. Isyana katılmadılar. Bu ahaliden oluşturulan Tekin birliği bizim ordularımızla birlikte kahramanca savaşmıştır. Türkmen ahalinin büyük bir kısmı yöneticilerden ve halk mahkemelerinden memnundular. Bunların arasinda su sorunu vardl. Murgab ve Tecen nehirlerinde az su vardı. Su miktarı düşüktü bu su da onlara yetmiyordu. Bunun nedenini daha öğrenemedik. Çünkü bu nehirlerin çıkış kaynağı Afganistan'daydı. Murgab Nehri klyılarındaki topraklarda çalışan Merv uyezdi Türkmenleri pamuk ekiminden çok iyi para kazanıyorlardı. Ama suların son zamanlarda azalması, ilerde bunların tarım işini tehlikeye sürüklüyordu. Maalesef 1912 yllında Türkmenler arasinda bazı kişiler ve partiler arasında küçük memurların yaptıkları icraatlardan dolayı anlaşmazlıklar ortaya çıkmıştır. Küçük koruma ajanlarının işe alındı ̆̆ zaman ve bunların kültürsüz Türkmenler arasından alınmasından dolayı Türkmenlerin başına tehlikeli yöneticiler gelmiştir. Rüşvet almaya başladılar. Rüşvet vermeyenleri hapse atıyorlardı. Oraya gönderdiğim Korgeneral İgnatoviç buradaki durumu araştırmış ve bu küçük koruma ajanlarının rüşvet vermeyen insanları siyasetten dolayı suçlayarak hapse attıkların görmüştür. Türkmenlerin en tehlikeli kısmı Yomudlardır. Bunların kışlıkları Iran'da bulunuyordu. Bu yüzden bunlar silah gücüyle de olsa bu işler için askere gitmeyeceklerini söylemişlerdir. Zamansız bir şekilde Iran'a göç eden Yomudlar Gürgen nehri rayonunda Rus ahaliye saldırmışlardır. Hive hanına tabi olan Yomud Türkmenleri, şuan bile Hive Hanlığ sakinleri için bir tehlike oluşturmaktaydılar. ${ }^{37}$ Yomudların bu kadar cesaretli olmalarının nedeni, bizim Türkistan'da ordumuzun az olmasından Iran'da Rus ordusunun güçsüz olduğuna dair dedikoduların olmasından ve Türklerin Tahran'a geleceğinden kaynaklanlyordu. Hive Hanlı̆̆ı'nda Türkmen Yomudların bu ayaklanmaların sebebi, Hive Hükümeti'nin zaylf olmasından ve bazen Yomudlara karşı haksızlık yapmalarından kaynaklanıyordu. ${ }^{38}$
\end{abstract}

Kuropatkin, genel valiliği boyunca isyan sırasında ve sonrasında yetkilerine dayanarak yaptığ 1 faaliyetleri adeta hesap verir hassasiyetinde rapor olarak çarlığa sunmuştur. Fakat genel valinin Türkistanlılara yönelik adeta kılını kıpırdatmayışı, bu hassasiyetin sadece çarlık menfaatleri için söz konusu olduğunu göstermektedir.

Raporun geneline bakıldığında, 25 Haziran fermanının olumsuz etkileri, dış güçler, Türkistanlıların bağımsızlık girişimleri, Türkistanlıların bölge yönetiminde çarlık rejimi aleyhine güçlü olması, bölgede Rus askerî birliklerinin yetersizliği, dinî ve ekonomik sebepler, arazilerin dağıtımındaki adaletsizlik, Rusların oryantalist bakış açısı, Rus ve yabacı idarecilerin yönetim zafiyeti ve halk üzerindeki baskısı gibi nedenler, Kuropatkin tarafindan isyanın nedenleri olarak çarlık merkezinin dikkatine sunulmuştur. Bu rapor içeriğinde bölge için yapmayı düşündüklerini ve önerilerini de general, çarlığa arz etmişti. Fakat Kuropatkin'in Türkistanlıların aleyhine uygulamaları ihtiva eden arzlarının uygulanmasına ne çarlığın ne de onun genel valilik ömrü yetmedi. Çünkü çarlık 1917 devrimiyle sona ererken Rusya' da yetki Geçici Hükümetin eline geçti. Çarlığın sadık hizmetkârı ve talebesi olan Türkistan son Genel Valisinin devrimle beraber hissesine ev hapsi ve ömür boyu askerlik mesleğinden mahrum olmak düştü.

3722 февраля 1917 г. Копия. РГВИА. Ф. 400. Оп. 1. Д. 4548. Л. 1-15 об. Опубл: Восстание 1916 г. 22 fevralya 1917 g. Kopiya. RGVİA. F. 400. op. 1. D. 4548. L.1-15 ob. s.12.

3822 февраля 1917 г. Копия. РГВИА. Ф. 400. Оп. 1. Д. 4548. Л. 1-15 об. Опубл: Восстание 1916 г. 22 fevralya 1917 g. Kopiya. RGVİA. F. 400. op. 1. D. 4548. L.1-15 ob. s.13. 


\subsection{Türkistan Komitesi Başkanı Şepkin Nikolay Nikolayeviç’in Raporu (27 Haziran 1917)}

1917 devrimi sonrasında işbaşına gelen Geçici Hükümet, çarlığın kendisine bıraktığı sorunlu miraslardan olan Türkistan millî ayaklanmasının tesir ve hasarlarını tespit etmek amaciyla bir komite kurdu. Geçici hükümetin kurduğu komitenin adı "Türkistan Komitesi" idi, komite başkanı olarak Şepkin Nikolay Nikolayeviç'i ${ }^{39}$ atadı. Şebkin, "Tanışpayev ile birlikte benim Semireçe'ye gitmem 1916 Kırgız isyanının sonlandırılması hedefleniyordu. Haziran ortalarına kadar bu misyonumuzu bitirip Taşkent'e döneceğimizi düşünüyorduk; ama Semireçe'ye geldiğimizde bu işin daha fazla süreceğini anlamıştık.” satırlarıyla geçici hükümete sundukları raporda Türkistan Komitesine atanma gerekçesini yazmıştır.

Komite başkanı Şebkin, Kırgızların sorunlarına, Kara Kırgızlar arasındaki farklı gruplara ve Rus devriminin etkilerinden söz ederek söz konusu rapora başladı. Raporda Türkistan Komitesi'nin isyan hakkındaki düşünceleri şöyledir:

"Prejeval, Pişpek ve Carkent'in bir kısmının Kara Kırgızların içinde feodalizm devam ediyor. Büyük ve küçük grup Kara Kırgızlar manapların emri altında yaşlyorlar. Kara Kırgız asilzadelerini tanınmış manap ${ }^{40}$ Sarıbagiş Şabdan seçiyor. Manap ona tabi olan fakirlerin her şeyine karar veriyordu. Fakirler ise buldukları her şeyin bir kısmını manaplara vermek zorundaydılar. Manaplar bunları korumakla yükümlüler. Onlar da manaplara vergi veriyorlardl. Bukara topraklart ile manaplar ilgileniyordu. 30 yılliğına kiraya verilen toprakların anlaşması Manaplar ve Ruslar arasında oluyordu. Kırgızlar arasında bir deyim vardır: "manap kurttur bukarada koyun sürüsüdür”. Yukarıda ismini söylediğim Manap Kıdır Türgen volostının manapı, bu manaplar içinde istisnadır. Hiçbir şey belli değildir. Artık bukara yani fakirler manaplardan kurtulmak istiyor. Bazen manaplar çok acımasız, sert bir şekilde fakirleri öldürüyorlardl. Pişpek uyezdinde Taş-Tübe'de fakirler manapların idaresinden çıkmışlardır. Burada Kırgızlar askerî vali İvanov'un Kazak birliğine çă̆ırıldıklarında gidiyorlardı. Ama bunların manapların idaresinden çıkma çabaları, Ruslar tarafindan engelleniyordu. Buraya yerli yöneticilik ve Halk Mahkemesinin kurulması ile her şey manapların eline geçti. 1904 yllında Kırgızlar bana yerleşik hayata geçmek isteyenlerin isimlerini söylemediler. Şunu söylemişlerdir: uyezd müdürü ögrenir ve manaplara söyler, manaplar da ${ }^{41}$ bizi cezalandırırlar. Bu sözler Rus Hükümeti için çok act verici bir durumdur. Bukara hareketi manaplar tarafindan engellenmiş ve üyeleri de halk mahkemelerinde cezalandırlmıştır. Bu mahkemelerde yalancı şahitler sayesinde bunların her birine 1,5 yıl hapis cezası verilmiştir. Geçen seneki isyanda da manaplar büyük rol oynadılar. Bazıları Hanlık hayalleri kurdu (Batırhaş-Tüp Volostı manapı, Mukuş Şabdanov Sarıbagiş volostı vs) diğerleri kendilerini han yardımcısı olarak görüyordu. Bukarayı ayaklandırmak çok kolaydı. Çünkü bukara manapların elindeydi. Kırgızların en verimli topraklarının ellerinden

39 Şepkin Nikolay Nikolayeviç (07.05.1854 - 15.09.1919). Geçici Hükümetin Özel Türkistan Komitesi Başkanı (07.04.1917).

4027 июня 1917 г. РГИА. Ф. 1291. Оп. 84. Д. 57. Л. 2-13.; 27 iyunya 1917 g. RGİA. F. 1291. Op. 84. D. 57. L. 2-13. s. 14.

4127 июня 1917 г. РГИА. Ф. 1291. Оп. 84. Д. 57. Л. 2-13.; 27 iyunya 1917 g. RGİA. F. 1291. Op. 84. D. 57. L. 2-13. s. 15. 
alınması bukara içinde bir kin oluşturmuş̧ur. İşçi alımı kanalıyla ve bunun yanlı̧̧ anlatılması ile bukaraların sabrı taştı ve isyan ettiler. Çok şaşırıyorum ki Rus yöneticileri ve göç idaresi memurları manapların ne kadar önemli olduğunu anlamıyorlar. Onlar, verdikleri bu yetkilerle manapları daha da güçlendiriyordu."

Rapordaki bu satırlar, isyanın tüm suçunu manaplara yükleme amacı gütmektedir. Oysaki gerçek hiç de böyle değildir. Her ne kadar Rus idarecilerini raporda eleştirse de, bu eleştirisi yine bölgenin kadim ahalisinin yönetimde söz sahibi olmasına ya da bağımsızlık düşüncelerine tıpkı çarlıkta olduğu gibi sömürü politikası zihnine sahip olmalarını açığa çıkarmaktadır. Raporda ayrıca "Geçmiş geride kaldı, gelecek için çalışmamız lazım. Kara Kırgızların daha da kültürlü olmalarını sağlamamız lazım. Demokratik Rusya'da manap yönetimine izin verilemez. Manaplara karşı mücadele etmemiz gerekir. Burada demokratik bir organizasyon kurmamı gereklidir. Mücadele zor olacaktır. Önemli hedefimiz devrimdir. ${ }^{42}$ Eğer gücümüz olursa bu devrimi gerçekleştireceğiz. Ĕger gücümüz olmazsa demokratik Rusya'da feodalizm devam edecektir." cümleleri bölgede kayıp olan Rus otoritesini sağlamaya yönelik bir örnek olarak görülmektedir.

Raporun devamında; "Bu Kara Kırgızlar arasında demokratik organizasyonu kurmaktan başka manaplarla "Çegın” için mücadele etmemiz gerekiyor. Yani manapların halktan topladı̆̆ vergi ve paraları bizim toplamamı gerekiyor. Çegın olarak adlandırdığımız vergiler, manapların cebine giden para ve manapların seçimlerde harcadıkları parayı milletten geriye toplaması sistemidir. Çegının böyle geniş manada kullanması dolayısıyla, çegın ile mücadele, manaplarla mücadelemizin en önemli kısmıdır. ${ }^{43}$ " Tespiti isyan sırasında manapların isyana kalkışan Türkistanlılara yaptığı ekonomik yardımın Rus idarecileri tarafından bilindiği izlenimini vermektedir. Zira raporun bu kısmında manaplar ve manapların gücünün yok edilmesi fikri, bir daha bölgede özgürlük ve vatan savunması yapılmaması için merkezin uyarılması anlamındadır.

\section{Türkistan Millî Ayaklanmasının Başlaması (1916)}

Ayrıca Jeleznyakov isyanın başlama olasılığının olmadığı bilgisini: "askerî işçi alımıyla ve bu askerî işçi alımının yanlış anlaşılması, yabancıların yani Kırgızların ve Kara-Kırgızların isyanına neden oldu ve durumlar bu kadar kötü hale geldi." ifadeleriyle isyana dair nedenleri ve gerekçeleri raporun bu bölümünde tamamlamıştır. Ayrıca Jeleznyakov, 3 Ocak 1916 tarih ve 7 numaralı raporunda İç İşleri Bakanlığı'na:44 “Kırgız ahalisi arasında askere çağrılma (25 Haziran fermanı) hakkında konuşmalar olduğunu, Devlet Dumasında bazı kişiler tarafindan Kırgızların askere alınması konusu ayrıntılı olarak incelenmiş, yabancılar konuya karşı

4227 июня 1917 г. РГИА. Ф. 1291. Оп. 84. Д. 57. Л. 2-13.; 27 iyunya 1917 g. RGİA. F. 1291. Op. 84. D. 57. L. 2-13. s.16.

4327 июня 1917 г. РГИА. Ф. 1291. Оп. 84. Д. 57. Л. 2-13.; 27 iyunya 1917 g. RGİA. F. 1291. Op. 84. D. 57. L. 2-13. s.17.

44 Ноябрь 1916 г. РГИА. Ф. 1292. Оп. 1. Д. 1933А. Л. 475-505.; Noyabr 1916. RGİA. F. 1292. Op. 1. D. 1933А. L. 475-505. s.13. 
olsalar da içlerinde bir propaganda yapmıyorlardı. Bu konuşmalar da kısa süre içinde sona erdi. Herkes normal hayatına döndü. ${ }^{45}$ " diye yazmıştı.

Fakat Polis müdürü, cephe gerisine askeri işçi alma meselesinin çok tartışılmadan ve karşı gelinmeden kabul edildiği bilgisini İç İşleri bakanlığına verdikten kısa süre sonra isyan başladı. Jeleznyakov isyanın başlamasını şu sözlerle bağlı olduğu bakanlığa aktarmıştır:

"Yabancıların askeri işlere alınma kararı oblast yöneticisine 1 Temmuz'da geldi. Bu kararı ne yöneticiler ne de yabancılar beklemiyorlardı. Hemen vali başkanlı̆̆ında bir toplantı yapıldl. Bu toplantıya beni çă̆ırmadılar. Daha sonra öğrendim ki yabancıların askeri işe alınması ile ilgili işe başlama kararını toplantıda almışlar. Yabancıların psikolojisini düşünmeden bu kararı almışlardır. Yöneticiler ve yabancılar ne yapacaklarını bilemediler bu karar karşısında herkes şaşkınlık içerisindeydi. Ölen askeri vali Folbaum yanına önde gelen insanları çağırarak yabancıların askeri işlere alınması konusunun neden önemli olduğunu onlara açıkladı. Bu konuyu vali anlattıktan sonra imparatorun sağlığ için "Ura" amin denildi. İşe alınma şu şekildeydi. İş̧i sayısına göre her volost bu işçileri seçerek, bu işçilerin malzemelerini, giyim kuşam, alet-edevat ve benzeri hazırlikları yapmak zorundayd. Bu durum isyanın başlamasına neden oldu. Valinin yanından dönen ve volostların önde gelen saygın kişileri emrin çardan olduğunu söylediler. Ahali buna inanmıyordu. Onların işe değil askere alınacaklarına inanıyorlardı. Emrin Beyaz Çardan geldiğine de inanmıyorlardı. Buhara Hanlı̆̆ bu durumu farklı anladl. Yerel yöneticilerin üst yöneticileri memnun etmek için saygın önde gelen kişileri rüşvetle yanlarına çekip bu yalanı uydurduklarına inanıyorlardı. ${ }^{46}$ ".

Kuropatkin raporunda: “Ayaklanmalar ilk olarak Semerkant'ta başladı. Türkistan'ın üç ana bölgesinden ilk 13 Temmuz'da Cizak uyezdinde bu ayaklanmalar isyan şekline dönüşı̈. Cizak'ta uyezd müdürü Albay Rukin acımasızca öldürüldü. Polis Capitan Zagotlov öldürüldü. Uyezdde ise Zaimin polisi Sokobolev Zaimin'nin Rus ahalisi orman bekçileri ve Tarım Bakanlı̆̆ istatistik memurlarl, dövülüp öldürüldüler. Cizak'ta toplam 83 Rus öldürüldü. 20 kişi yaralanmış 70 kişi ise esir alınmıştır. Esirlerin birçoğu kadın ve çocuktur. İsyan daha sonra tüm Türkistan'da Fergana, Sır Derya, Zakapinskiy ve Semireçe vilayetlerine sıçradı. ${ }^{47}$ " satırlarıyla isyanın başlaması hakkında bilgi vermiştir.

\section{Sonuç}

Ruslar 19. asrın sonlarına doğru Türkistan bölgesini işgal etti. İşgal sonrası kendi maksatlarına hizmet edecek idari düzenlemeler yaptı. Yaklaşık elli yıl bölgeyi nerdeyse sorunsuz bir şekilde sömüren çarlık, ömrünü tamamlamak üzereyken 25 Haziran fermanını yayımladı. Fermanın amacı, elli yıldır vesayet altında bulunan, askerlikten muaf bölge ahalisinin amele

45 Ноябрь 1916 г. РГИА. Ф. 1292. Оп. 1. Д. 1933А. Л. 475-505.; Noyabr 1916. RGİA. F. 1292. Op. 1. D. 1933A. L. 475-505. s.14.

46 Ноябрь 1916 г. РГИА. Ф. 1292. Оп. 1. Д. 1933А. Л. 475-505.; Noyabr 1916. RGİA. F. 1292. Op. 1. D. 1933 A. L. 475-505. s. 14.

4722 февраля 1917 г. Копия. РГВИА. Ф. 400. Оп. 1. Д. 4548. Л. 1-15 об. Опубл: Восстание 1916 г. 22 fevralya 1917 g. Kopiya. RGVİA. F. 400. op. 1. D. 4548. L.1-15 ob. s.2. 
de diyebileceğimiz cephe gerisi işler için orduya alınmasıydı. Türkistanlılar fermana çok sert tepki vermişlerdi. Daha sonra bu tepkiler 1916 Türkistan Millî Ayaklanmasına dönüştü. İsyanın çok fazla sebebi vardır. Bu sebeplerin kökeni Rusların bölgede icra ettikleri sömürge siyasetinde çok açık olarak gözükmektedir. Mesela Türkistanlıların arazilerinin gasp edilmesi, onlara idarede görev verilmemesi, sosyal yaşam biçimlerine müdahale edilmesi, yer altı ve yer üstü kaynaklarının çarlık lehine vergi ya da başka isimler altında kadim ahaliden metazori alınması, Türkistanlılara Rus idarecileri ve ahalisi tarafından alçaltıcı bir tavır takınılması ilk akla gelenlerdir.

Değerlendirmeye tabi tutuğumuz raporlar; Türkistan son genel valisi, bölge jandarma ve polis müdürü ile Türkistan Komitesi tarafından ilk ikisi çarlığa üçüncüsü ise geçici hükümete sunulmuştur. Üç raporda da isyanın nedenleri, isyanın çıkışı birbirine paralel düşüncelerle dile getirilmiştir. Bu raporlarda çarlığın elli yıl boyunca Türkistan' da icra ettiği sömürü siyasetinin gizlenmeye çalışıldığını görmekteyiz. İsyanın nedenleri, çarlığı dışta tutarak, kısmen bazı Rus yerel idarecilerin yaptıkları görevi kötüye kullanmalarına dayandırılarak basite indirilmiştir. Ama isyanın çıkış suçunu Türkistanlıların cahilliğine, fermanı anlamamalarına, özgür ve bağımsız yapılanmalarına karşı çıkılarak manaplara ve Türkistanlılara fatura edildiğini söyleyebiliriz.

Hakem Değerlendirmesi: Dış bağımsız.

Çıkar Çatışması: Yazar çıkar çatışması bildirmemiştir.

Finansal Destek: Yazar bu çalışma için finansal destek almadığını beyan etmiştir.

Peer-review: Externally peer-reviewed.

Conflict of Interest: The author has no conflict of interest to declare.

Grant Support: The author declared that this study has received no financial support.

\section{Kaynakça/References}

\section{Rus Arşiv Raporları}

Ноябрь 1916 г.РГИА. Ф. 1292. Оп. 1. Д. 1933А. Л. 475-505.;Noyabr 1916. RGİA. F. 1292. Op. 1. D. 1933A. L. 475-505.

22 февраля 1917 г. Копия. РГВИА. Ф. 400. Оп. 1. Д. 4548. Л. 1-15 об. Опубл: Восстание 1916 г. 22 fevralya 1917 g. Kopiya. RGVİA. F. 400. op. 1. D. 4548. L. 1-15 ob.

27 июня 1917 г. РГИА. Ф. 1291. Оп. 84. Д. 57. Л. 2-13.; 27 iyunya 1917 g. RGİA. F. 1291. Op. 84. D. 57. L. 2-13.

Sentyabrya 1915 g. AVPRİ. F. Sredne aziatskiystol. Op. 486. D.360 b. L. 5-5 ob.,S.1-4, 8-13, 31-33.; 21 сентября 1915 г. АВПРИ. Ф. Средне азиатскийстол. Оп. 486. Д. 340 б. Л. 5-5 об. С. 1-4, 8-13, 31-33.

\section{Araştırma Eserler}

Hayit, Baymirza. Türkistan Rusya ile Çin Arasında. Ankara,1975.

Historia rossi centralnaya aziya $v$ sostave rossiysky imerii, novoye literaturnoye obozreniye evropeyskiy universitet v: Saint-Petersburg, 2008. 
Kurat, Akdes Nimet. Rusya Tarihi Başlangıçtan 1917’ye Kadar. TTK Ankara, 2014.

N.A. Maeva. Russkiy Turkestan sbornik, izdannıy popovodu politemniceskoyv istavki, VI ruskpervıy, geografia i statistika. podredakciyu Moskva v universitet skoytipograsii katkov i k,1872.

Nikolayeviç, Belyavskiy Nikolay. MaterialıpoTurkestanu. Saint-Petersburg, 1885.

Özkan, Murat Türkistan 'ın Keşif Çă̆l. Kronik Kitap. İstanbul, 2019.

Piyade Binbaşı Nazmi Bey. Kafkasya ve Türkistan (Kafkasya, Asyâ-yıVustâ ve Türkistan Vilâyetleri Buhâra ve Hîve Hanlıklarl Coğrafî, Siyasî, Tarihî ve İstâtistikî Mücmel Malûmât). İstanbul: İstanbul Matbaa-i Askeriye, 1918.

Sarsambayev, M.A. kazakhskoye hastvo kak suvernoye gosudarstvo srednevekovoy epokhi, institut zakonadatelstva respuliki kazakhstan: Astana, 2015.

Şuşkova, M. Y. Organizatsiya upravleniye Turkestanom v naçale XX veka, Dissertatsiya na soiskaniye uçenoy stepeni kandidata istoriçeskiy nauk, Rossiyskiy gosudarstvennıy gumaniternıy universitet Moskva: Moskva, 2015.

Togan, A.Zeki Velidi. Umumi Türk Tarihine Giriş. Cild I En eski Devirden 16.Asra kadar 3.baskı. İstanbul, 1981. Vyatkin, M. Oçerki po istorii Kazahskoy SSR: Top pervıy s drevneyşıh vremen po 1870. OGİ: Gospolitizdat, 1941.

\section{Makaleler}

Özkan, Murat. "Petro’nun Altın Düşleri İvan Dmitrieviç Buhgolts’un Yarkend Keşif Seferi (1714-1716)”. Hacettepe Türkiyat Araştırmaları Dergisi, Bahar (32) 2020. 187-202.

---- “Bekoviç Gibi Kaybetmek: Aleksandr Bekoviç Çerkasskiy’in 1717 Hive Seferi”. Marmara Türkiyat Araştırmaları Dergisi, 2018; V (1): 93-111.

Koç, Dinçer. “Buhara Hanlığı'na Gelen Rus Diplomat ve Askerler”. Türk Dünyası Araştırmaları, 115(227), 2017. 61-90.

Şen, Muhammet-Çiftçioğlu, Ferdi. “Türkistan Genel Valisi Aleksey Nikolayeviç Kuropatkin’in Türkistan İzlenimleri (1916)". Akademik Tarih ve Düşünce Dergisi, 5(17), 2018. 181-209.

Ükten, Selim Serkan. “16-18. Asırlarda Buhara Hanlığı’na Gelen Batılı Seyyahlar ve Seyahatnameleri”. Eskişehir Osmangazi Üniversitesi Sosyal Bilimler Dergisi, 18(2), Aralık 2017. 137-164.

Vurgun, Seda Y1lmaz. “1916 Türkistan İsyanı”, Sutad, Güz (40), 2016. 315-325.

Yazıcı Serkan-Çelik, M. Bilal. “Türk Tarihinde Bir Rus General: Aleksey Nikolayeviç Kuropatkin(1848-1925)”. Sakarya Üniversitesi, Fen Edebiyat Dergisi 2008. 141-142. 